Review

\title{
Sustainability reporting among mining corporations: a constructive critique of the GRI approach
}

\author{
Alberto Fonseca ${ }^{\mathrm{a}, *}$, Mary Louise McAllister $^{\mathrm{b}}$, Patricia Fitzpatrick ${ }^{\mathrm{c}}$ \\ ${ }^{a}$ Department of Environmental Engineering, School of Mines, Federal University of Ouro Preto, Morro do Cruzeiro, Ouro Preto, MG 35400-000, Brazil \\ ${ }^{\mathrm{b}}$ Environment and Resource Studies Department, University of Waterloo, ON N2L 3G1, Canada \\ ${ }^{\mathrm{C}}$ Department of Geography, University of Winnipeg, Winnipeg, MB R3B 2E0, Canada
}

\section{A R T I C L E I N F O}

Article history:

Received 14 August 2012

Received in revised form 29 November 2012

Accepted 29 November 2012

Available online $\mathrm{xxx}$

\section{Keywords:}

Sustainability reporting

Global reporting initiative (GRI)

Mining sustainability

Sustainability assessment

Corporate accountability

Mining and metals

\begin{abstract}
A B S T R A C T
The environmental crisis is giving rise to growing public demand for socially responsible and ecologically viable mining practices. Large mining corporations are responding by advancing the idea of a sustainable mining industry. These responses are accompanied by concerted efforts to advertise a company's relative progress in this direction through the publication of sustainability reports based on the Global Reporting Initiative (GRI) Framework. Many scholars contest the effectiveness of that framework, arguing that GRIbased reports can mislead decision-makers who are concerned with sustainability, or even camouflage unsustainable practices, particularly at the site level. Few scholars, however, have scratched below the surface of criticism in order to consider how to improve the effectiveness of that framework. This article takes a closer look at this problem by answering the following question: What needs to be changed in mining corporations' GRI-based frameworks for the purpose of promoting more meaningful and reliable sustainability performance information? This article followed a qualitative methodological approach based on literature reviews and 41 semi-structured interviews. The analysis was guided by an evaluation of the extent to which the predominant GRI-based approach to sustainability reporting meets a number of principles of sustainability assessment and reporting, known as the BellagioSTAMP principles. This paper outlines a number of specific changes that should be promoted in mining corporations' frameworks if their reports are to provide meaningful and accurate information about sustainability progress. Such changes include a more systematic consideration of site-level performance, scenario building, and legacy effects. Overall, this article corroborates the view that meaningful and reliable standardized disclosures of contributions to sustainability are unlikely to emerge any time soon. The geographical dispersion of mining facilities imposes substantial difficulties to the contextualization of sustainability evaluations.
\end{abstract}

(c) 2012 Elsevier Ltd. All rights reserved.

\section{Introduction: the spread of GRI reporting among mining corporations}

The global mining industry's adverse socio-environmental impacts are stimulating the emergence of anti-mining campaigns, movies, and civil society protests and reports throughout the world (Ali, 2003; Cameron, 2009; Earthworks, 2012; FOE, 2002; Greenpeace, 2010; Kocsis, 2004; McAller and McElhinney, 2006; MiningWatch, 2004; PRI, 2010; Rotheroe, 2000; WWF, 2007). The resulting publicity inevitably damages the industry's reputation. Such reputational problems are often associated with large mining corporations, as these entities have become responsible for more

\footnotetext{
* Corresponding author. Tel./fax: +55 3135591496

E-mail address: albertof@em.ufop.br (A. Fonseca).
}

than $80 \%$ of the world's non-fuel mineral production (Ericsson, 2008).

Partly in reaction to criticism, large publicly-traded mining companies increasingly promote sustainability initiatives, such as the Global Mining Initiative (GMI). The GMI was first championed in 1998 by nine Chief Executive Officers (CEOs) from giant companies (Danielson, 2006). One of the main outcomes of the GMI was the establishment of the International Council on Mining and Metals (ICMM) in 2001. The ICMM is a global industry organization that represents many of the world's largest mining companies in sustainability-related issues. Its main objective is to serve as an agent for change on issues relating to mining and sustainability.

ICMM's programs are implemented by 22 of the world's largest mining companies and promoted by 34 mining and commodity associations (ICMM, 2012). The Sustainable Development Framework (SDF) is one of the Council's most relevant programs; it

0959-6526/\$ - see front matter (c) 2012 Elsevier Ltd. All rights reserved. http://dx.doi.org/10.1016/j.jclepro.2012.11.050 
consists of a set of ten principles, sustainability reporting, and external third-party assurance. All member companies are expected to implement the SDF and thus publish independentlyverified reports on their sustainability performance. At the core of the framework is a requirement to use the Global Reporting Initiative (GRI) framework (GRI, 2006b) and its Mining and Metals Sector Supplement (MMSS) (GRI, 2010). GRI is a multi-stakeholder non-profit Amsterdam-based organization providing global standards in sustainability reporting. Its reporting framework, first piloted in the late 1990s and now in its third version, known as GRI G3, has become the de facto standard across many industrial sectors, including mining (Skouloudis et al., 2009).

Driven by ICMM and a global corporate trend, mining corporations increasingly publish GRI-based sustainability reports. According to the Global Mining Reporting Survey (KPMG, 2006), 40 out of the world's 44 major global mining companies produce annual sustainability reports. According to the GRI database, in 2011, 102 mining companies published reports, 95\% of which based on the GRI framework (GRI, 2012b). The output of annual GRI reports, however, is likely to be larger, since many companies do not list their reports on the GRI database.

The proliferation of sustainability reports in the mining sector has attracted the attention of growing numbers of analysts and scholars, whose analytical approach to this phenomenon has been predominately descriptive (Deloitte, 2007; Guenther et al., 2006; Jenkins, 2004; Jenkins and Yakovleva, 2006; Matthews et al., 2004; Mudd, 2007a, 2007b; Peck and Sinding, 2003; Perez and Sanchez, 2009; Robertson and Jack, 2006). Such studies are primarily confined to characterizing reported data, assessing quality, and identifying trends. Overall, research findings indicate that GRIbased sustainability reporting is on the rise and is likely to continue to gain salience in the sector, despite current methodological difficulties and information gaps.

Attempts to render sustainable development down into a few definitional words or sentences in the context of the mining industry frequently result in a reductionist approach that fails to capture complexity and scale. For example, sustainability has often been defined in the context of a mine site or community. Such definitions suggest that sustainable development might be achieved where a net social and biophysical benefit can be realized from the lifecycle of a mine and beyond (Veiga et al., 2001), where there are continuous socio-environmental improvements (Hilson and Murck, 2000) or where a company has gained a social license to operate in a community (Gifford and Kestler, 2008). The difficulties with such definitions is that they do not hold in a global context because they are either site specific, or they do not take into account cumulative effects, the lifecycle of mineral or mineral product, or trade-offs operating at different spatial and temporal scales.

The term "sustainability" or "responsibility" is frequently used to describe corporate non-financial reports. Several analysts, however, claim that such reports overlook fundamental tenets of sustainable development (Azapagic, 2004; Bebbington, 2001; Gray, 2010; Gray and Milne, 2005; Milne and Gray, 2007, p. 6; Moneva et al., 2006; Mudd, 2009). Accordingly, there is a growing call for enhanced approaches to reporting, in which companies use more holistic and integrative frameworks to assess contributions to sustainability (Henriques and Richardson, 2004). Few studies, however, explore ways to bring about this change. This article attempts to address this challenge, while answering the following question: What needs to be changed in mining corporations' GRIbased framework for the purpose of promoting more meaningful and reliable sustainability performance information? In order to achieve this goal, this piece first explains the GRI framework and the debate surrounding its limitations and flaws, followed by the explanation of the methodology and the BellagioSTAMP principles. In the following section, key BellagioSTAMP principles are used to conduct a gap analysis of the GRI. Finally, the paper outlines a number of specific changes that should be considered in the strengthening of mining corporations' sustainability reporting practices.

\section{The GRI approach to assessing and reporting sustainability}

Unlike the sustainable development concept, whose genesis can be directly associated with the 1987 Brundtland Commission report (WCED, 1987), the term "sustainability reporting" was brought to life during years of evolution in the field of social and environmental accountability (UNEP and KPMG, 2006). The Global Reporting Initiative provides one of the most influential definitions of sustainability reporting: "Sustainability reporting is the practice of measuring, disclosing, and being accountable to internal and external stakeholders for organizational performance towards the goal of sustainable development" (GRI, 2006b, p. 3). GRI's sustainability reporting framework is in its third version, known as GRI G3. This version is made up of three main elements providing guidance on "how to report" and "what to report" (Fig. 1), described as follows (GRI, 2006b):

- Reporting guidelines: The guidelines are the cornerstone of the GRI G3. They set quality and content principles, as well as managerial and performance indicators. The principles for defining content include materiality, stakeholder inclusiveness, sustainability context, and completeness. The indicators (about 130) cover several thematic categories, including organizational, managerial, economic, environmental, social, human rights, society, and product responsibility issues;

- Sector supplements: The supplements provide additional guidance and indicators for sector specific issues. One of the supplements is the aforementioned Mining and Metals Sector Supplement; and

- Indicator protocols: The protocols provide definitions and technical and methodological guidance on each of the performance indicators of the guidelines.

The appendix presents a summary table of the main indicators available in the Reporting Guidelines and the Mining and Metals

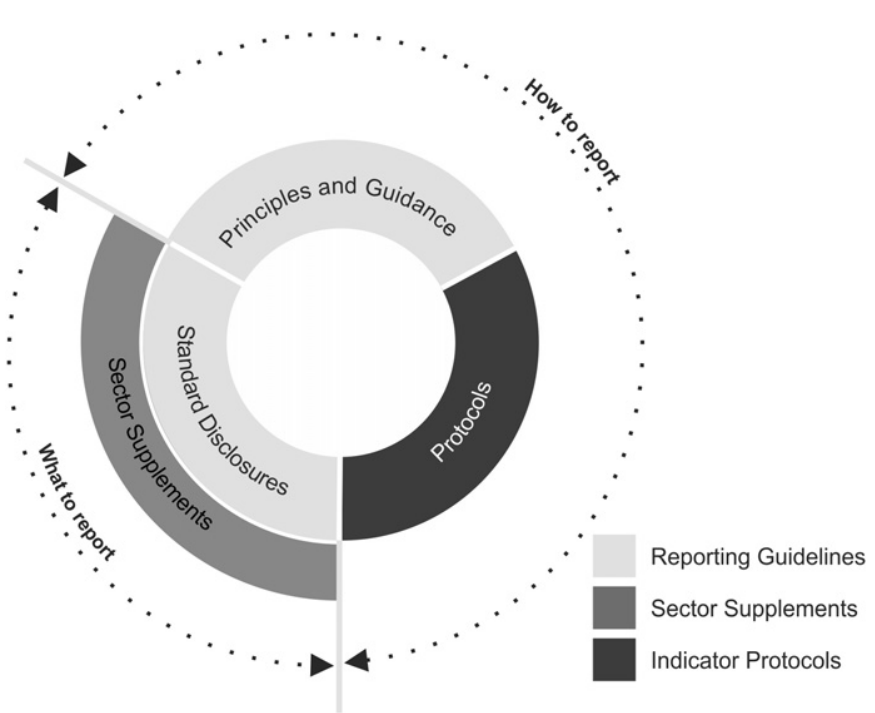

Fig. 1. GRI G3's main elements. Source: GRI (2006a, b). 
Sector Supplement. The latest G3 version of the GRI framework introduced an Application Level procedure to "demonstrate a pathway for incrementally developing, expanding, and deepening approaches to reporting over successive cycles" (GRI, 2006a, p. 4). The procedure helps companies to gauge their maturity levels in sustainability reporting. It guides organizations to self-declare their reporting level $(\mathrm{A}+, \mathrm{A}, \mathrm{B}+, \mathrm{B}, \mathrm{C}+$, or $\mathrm{C})$, or hire an external organization to verify their self-declaration. The framework's many indicators are non-integrated, i.e. they are required to be evaluated in isolation, with little or no consideration for its synergies and interactions across and within different operational sites.

Concerns have accompanied the rise of GRI-based sustainability reporting with respect to its limitations and potential negative consequences. Some analysts claim that the introduction of nonintegrated sustainability reporting frameworks, such as GRI's, was important insofar as it helped organizations to widen the transparency and accountability of a number of social and environmental issues. But, in doing so, this approach contained within it an "Achilles heel", namely, "that there is an essential conflict between financial and other bottom lines, which, for the foreseeable future at least, the financial will always win" (Gray and Milne, 2002, p. 4). In contrast, Gray and Milne argue that an effective approach to sustainability reporting, would require "a detailed and complex analysis of the organization's interactions with ecological systems, resources, habitats, and societies, and interpret this in the light of all other organizations' past and present impacts on those same systems" (2002, p. 6). Such an argument is further elaborated by Moneva et al. (2006), who claim that the GRI approach to reporting sustainability has significant problems that may ultimately camouflage organizations' un-sustainability. After all, companies who follow the GRI framework tend to focus on specific issues within their organizations, running "the risk of losing sight of the big picture for sustainability..." (Moneva et al., 2006, p. 135). Similar arguments, becoming increasingly prevalent in the literature, warn that this practice can actually lead to flawed decision-making (e.g. Aras and Crowther, 2008; Byrch et al., 2007; Crowther et al., 2006; Laine, 2005; McElroy et al., 2008; Morhardt, 2009). As noted earlier, however, few studies have gone far beyond the realm of criticism to understand how sustainability reporting frameworks can be made more meaningful; that is, how frameworks can be enhanced to enable assessments and communications that reveal the complex interactions of mining organizations with society and ecosystems over time.

\section{A methodological approach based on the BellagioSTAMP principles}

This research study adopted a qualitative methodological approach in order to understand how the predominant framework to reporting sustainability in the mining sector, namely the GRI G3 meets a number of widely accepted principles of sustainability assessments and communications, known as BellagionSTAMP. The evaluation is based on a content analysis of GRI G3's technical documents as well as of sustainability reports prepared by mining companies. Further insights are drawn from literature reviews and semi-structured confidential interviews with 41 key informants who use, train, research, promote, and provide services in connection with sustainability assessment and reporting. Key informants were selected because of their extensive applied and/or theoretical knowledge in sustainability assessment and reporting, particularly in the mining sector. The interviews were stored and coded in the NVivo 8 software, in order to facilitate the analysis and ensure confidentiality. This study, although acknowledging that "all [literature] reviews are partial in some way or another" (Hart, 1998, p. 25), strove to be attentive to a plurality of sources and perspectives available in hundreds of publications from academia, industry and NGOs sources.

Sustainability decision-making in the mining, or any other, sector needs to be based on indicators that identify the interactions of organizations with the environment. Decision-makers also need a framework that can enable the selection and operationalization of the most relevant indicators. The "sustainability reporting framework", in itself a debatable term, is described in several ways, often on an ad hoc basis. In its simplest conception, a sustainability reporting framework is a structure comprised of indicators, indices, conceptual models, principles, criteria, goals, policies, among others.

Almost 900 sustainability indicators systems or frameworks have been created worldwide (IISD, 2012a). Despite such efforts, the effective design of frameworks remains a rather difficult task; a variety of approaches can underpin such a purpose. Temporal orientation, quantity of indicators, aggregation and integration levels, spatial focus, and systems conceptualization: These are some of the many aspects that can be taken into account in the framework design. Such diversity provides policymakers and standardsetters with a range of alternatives that may suit different purposes and contexts. At the same time, however, such a plurality can obscure the identification of the most effective approaches, i.e. those approaches that can indicate the short and long-term behavior of observed social and ecological systems.

Recognizing the need for consensus over the desirable characteristics of effective sustainability evaluation and communication frameworks, a group of sustainability measurement practitioners and researchers developed a set of eight criteria, known as the Bellagio Principles for Sustainability Assessment principles. The Bellagio Principles are not yet another framework; rather, they constitute a set of principles that can be used to design or evaluate existing frameworks. The first version of the Bellagio Principles included 10 principles that were unanimously endorsed in Bellagio, Italy, in 1996. The value and sense-making power of those principles have been corroborated by their extensive application in sustainability studies (Becker, 2004; Bell and Morse, 2008; Bossel, 2001; Devuyst, 2000; Diesendorf, 2001; Dunphy et al., 2000; Geßner et al., 2001; Hodge et al., 1999; Kay, 2000; McCool and Stankey, 2004; Muula, 2007; Piper, 2002; Schertenleib, 2000; Steurer et al., 2005). The principles were revised in 2009 by the IISD and OECD to become more influential and concise, while reflecting the newest scientific research and political context. The newest version (see Table 1) includes eight principles, concisely known as BellagioSTAMP, which were unanimously endorsed by a group of sustainability assessment experts from across the globe who met once again in Bellagio, Italy (IISD and OECD, 2010).

The Bellagio Principles were tested, updated, and repeatedly endorsed by many experts in the field. For these reasons, they are adopted here to evaluate the practice of GRI reporting by mining corporations. The analysis focused on principles $1,2,3$ and 4 , which are arguably the most relevant ones in terms of affecting the design and reliability of the GRI framework.

\section{Results: does the GRI G3 deserve the BellagioSTAMP of approval?}

\subsection{Principle 1: guiding vision}

The GRI G3 emphasizes the overall goal of sustainable development as a necessary vision to frame reporting, although it does not explicitly mention the goal of delivering "well-being within the capacity of the biosphere to sustain it for future generations". The framework, however, does mention the need to respect the carrying capacity of the biosphere through its "Sustainability 
Table 1

BellagioSTAMP principles.

\begin{tabular}{|c|c|}
\hline Principles & Description \\
\hline 1. Guiding vision & $\begin{array}{l}\text { Assessing progress towards sustainable } \\
\text { development is guided by the goal to } \\
\text { deliver wellbeing within the capacity of the } \\
\text { biosphere to sustain it for future } \\
\text { generations. }\end{array}$ \\
\hline 2. Essential considerations & $\begin{array}{l}\text { Sustainability Assessments consider: The } \\
\text { underlying social, economic and } \\
\text { environmental system as a whole and the } \\
\text { interactions among its components; The } \\
\text { adequacy of governance mechanisms; } \\
\text { Dynamics of current trends and drivers of } \\
\text { change and their interactions; Risks, } \\
\text { uncertainties, and activities that can have } \\
\text { an impact across boundaries; and } \\
\text { Implications for decision making, including } \\
\text { trade-offs and synergies. }\end{array}$ \\
\hline 3. Adequate scope & $\begin{array}{l}\text { Sustainability Assessments adopt: } \\
\text { Appropriate time horizon to capture both } \\
\text { short and long-term effects of current } \\
\text { policy decisions and human activities; and } \\
\text { Appropriate geographical scope ranging } \\
\text { from local to global. }\end{array}$ \\
\hline 4. Framework and indicators & $\begin{array}{l}\text { Sustainability Assessments are based on: A } \\
\text { conceptual framework that identifies the } \\
\text { domains that core indicators have to cover; } \\
\text { The most recent and reliable data, } \\
\text { projections and models to infer trends and } \\
\text { build scenarios; Standardized measurement } \\
\text { methods, wherever possible, in the interest } \\
\text { of comparability; and Comparison of } \\
\text { indicator values with targets and } \\
\text { benchmarks, where possible. }\end{array}$ \\
\hline 5. Transparency & $\begin{array}{l}\text { The assessment of progress towards } \\
\text { sustainable development: Ensures the data, } \\
\text { indicators and results of the assessment are } \\
\text { accessible to the public; Explains the } \\
\text { choices, assumptions and uncertainties } \\
\text { determining the results of the assessment; } \\
\text { Discloses data sources and methods; and } \\
\text { Discloses all sources of funding and } \\
\text { potential conflicts of interest }\end{array}$ \\
\hline 6. Effective communication & $\begin{array}{l}\text { In the interest of effective communication, } \\
\text { to attract the broadest possible audience } \\
\text { and to minimize the risk of misuse, } \\
\text { Sustainability Assessments: Use clear and } \\
\text { plain language; Present information in a fair } \\
\text { and objective way, that helps to build trust; } \\
\text { Use innovative visual tools and graphics to } \\
\text { aid interpretation and tell a story; and Make } \\
\text { data available in as much detail as reliable } \\
\text { and practical }\end{array}$ \\
\hline 7. Broad participation & $\begin{array}{l}\text { To strengthen their legitimacy and } \\
\text { relevance, sustainability assessments } \\
\text { should: Find appropriate ways to reflect the } \\
\text { views of the public, while providing active } \\
\text { leadership; and Engage early on with users } \\
\text { of the assessment so that it best fits their } \\
\text { needs }\end{array}$ \\
\hline 8. Continuity and capacity & $\begin{array}{l}\text { Assessments of progress towards } \\
\text { sustainable development require: Repeated } \\
\text { measurement; Responsiveness to change; } \\
\text { Investment to develop and maintain } \\
\text { adequate capacity; and Continuous learning } \\
\text { and improvement }\end{array}$ \\
\hline
\end{tabular}

Source: IISD and OECD (2010).

Context" principle. This reporting principle requires a discussion about

(...) the performance of the organization in the context of the limits and demands placed on environmental or social resources at the sectoral, local, regional, or global level. For example, this could mean that in addition to reporting on trends in ecoefficiency, an organization might also present its absolute pollution loading in relation to the capacity of the regional ecosystem to absorb the pollutant. (GRI, 2006b, p. 11).

The GRI G3 does not include overall indicators and specific guidance on well-being, although it does cover dozens of indicators on social, human rights, labor practices, environmental protection, among others, that are related to, and can promote, well-being. Moreover, the MMSS, provides further guidance on the guidelines of the GRI G3 by explicitly and repeatedly corroborating the need to consider the well-being of employees and communities, though not "necessarily" those of future generations (GRI, 2010).

Surveys about the state of sustainability reporting among mining corporations, for the most part, show that these companies are framing their report as a response to the vision of sustainable development (KPMG, 2011; UNEP et al., 2010; Waard and Kamp-Roelands, 2009). However, they also reveal that companies are not fully complying with the GRI G3 guidelines. McElroy and his colleagues (2008) noticed that the aforementioned Sustainability Context principle was among the most critically overlooked aspects by reporters.

An analysis of many mining companies' sustainability reports from the period of 2006-2010 revealed that some GRI reporting principles, like materiality (or relevance of reported information), have been increasingly addressed. None of the analyzed reports, however, clearly explained how the Context Principle was addressed. This gap was corroborated by many participants who were interviewed for the purposes of this particular research project here. One of them coming from the perspective of the research community explains: “(...)[Sustainability Context] is not happening in any significant degree. I also believe that particular principle, among the 10 or 11 principles, is probably the least in compliance" (Key informant RD-1).

The goal of sustainability as guiding vision, as prescribed in the BellagioSTAMP, seems to be clearly stated by the GRI G3, but overlooked by mining corporations. As McElroy et al. (2008) note, this lack of connection between guidance and practice is probably a result of conceptual and practical difficulties in the process of contextualizing information across geographical regions. Such difficulties are particularly pronounced in the mining sector, because, in addition to aggregating data from different sites, mining companies also have to account for mineral depletion and scarcity across geographical scales.

\subsection{Principle 2: essential considerations (systemic and holistic view)}

The second BellagioSTAMP principle implies that sustainability evaluations should adopt a systems approach with due regard to holism as opposed to reductionism. The earlier version of the BellagioSTAMP referred to this principle as "Holistic Perspective" (Hardi and Zdan, 1997). With the exception of the need to consider adequate governance mechanisms, all other requirements of the above principle (see Table 1 ) reflect the view that indicators must be drawn from interconnected social, economic and environmental systems. Yet the GRI framework was repeatedly criticized in the literature for being reductionist and promoting the analysis of dozens of indicators that neglect interactive effects; and did not clearly relate to each other nor to the state of the socio-ecological systems from which they are drawn. As a result, sustainability reports prepared by mining corporations, like the ones of other sectors, have been missing the "big picture" and run the risk of misinforming decisionmakers. Many of the interviewees corroborated the existence of this problem in mining companies' sustainability reports. A mining practitioner tried to explain why: 
I think we have not effectively reported on our overall impact or contribution to the system that we are within. I think it is partly due to the fact that there are very few other drivers that are pushing us, industries, to look at their operations from a context of how they fit into the overall ecosystem. And so, we fall back to permits and everything fall back to performance indicators of what are our compliance for example. (Key informant MP-1)

The lack of use of the jargon of the systems and complex systems literature may suggest that a holistic or systemic perspective is fully dismissed by the GRI G3 and its MMSS. But the framework does guide organizations to report their performance as it relates to the "context" of communities and ecosystems. The framework also touches on the need to consider risks and uncertainties across boundaries by including an indicator that asks for an "explanation of whether and how the precautionary approach or principle is addressed by the organization" (GRI, 2006b, p. 23). Such an indicator often results in nebulous statements by mining companies about their strategies and governance approaches (e.g. BHP Billiton, 2009; Freeport-McMoRan, 2008; Nippon, 2007; Rio Tinto, 2007; Teck, 2007; Vale, 2010; Xstrata, 2009).

Another relevant requirement of the second principle is the need to understand synergies and trade-offs among indicators in the reporting process. As one expert in mining sustainability assessment notes, the power of the sustainability concept lies in its ability to integrate economy, people and the environment in forward-looking decision making (Hodge, 1997). Such a requirement was partly reflected in the previous version of the GRI framework, the G2, which acknowledged that addressing sustainability in terms of pillars of economic, environmental, and social indicators "can sometimes lead to thinking about each element in isolation rather than in an integrated manner" (GRI, 2002, p. 2). The GRI G2 did not include integrated indicators or guidance on how to address trade-offs, but it encouraged users to search for them:

Reporting organizations should also include other content, particularly integrated performance indicators, identified through stakeholder consultation. This information and these indicators may relate to sector- or geography-specific issues pertinent to the organization. (GRI, 2002, p. 16)

The GRI G3 and its MMSS do not explicitly require or encourage indicator integration. Not surprisingly, most mining companies, if not all of them, are publishing reports with 'silos' of sustainability information. Many authors and mining stakeholders consulted for this research are concerned about this problem. According to one of them, this lack of 'systemic' or 'holistic' disclosures is partly a result of the lack of understanding of complex systems among industry people (Key informant IC-2). But a mining sustainability expert disagrees with this view. He argues that the problem is not so much a lack of understanding of what systems or complex systems means, but of how to apply it.

Companies will probably argue that they have a systemic view of their activities and that their sustainability reports reflect systems thinking, but an external stakeholder might disagree. People often concur that system thinking is necessary; disagreements surface when it comes to its operationalization. (Key informant ME-3)

Julie Richardson (2004), in her critical review of the state of the art of sustainability reporting, pointed out that meaningful progress in this practice will depend on a stronger operationalization of systems thinking. She proposes a number of conceptual changes to the predominant non-systemic approach that companies should consider in future enhancements of their reporting approaches.

\subsection{Principle 3: appropriate geographical and temporal scope}

The GRI G3 and its MMSS adopts a predominately retrospective and non-geographical approach to the selection of indicators, thus promoting sustainability reports that largely fail to meet the principle above. The GRI framework follows a financial accounting rationale, and guides companies to report on organizational issues. Such an approach reflects the lack of systems thinking:

(...) it is, of course, not the impact of individual organizations that matters but the interactions and total impacts that a range of organizations has on an ecosystem's carrying capacity. This requires a level of analysis that is quite different from the analysis assumed by organizational reporting, and one that requires decision-taking and action to be operable at, for example, local, ecosystem and/or national level - not at the level of organization itself. (Gray and Milne, 2005, p. 78)

The purpose of the GRI framework is to promote standardized "organizational performance towards the goal of sustainable development (...)" among organizations of any size, sector, or location, "(..) from small enterprises to those extensive and geographically dispersed operations" (GRI, 2006b, p. 3). To enable such an ambitious goal, GRI guides organizations to identify and report performance on the most relevant sustainability issues across the organization, with very little guidance about how to consider geographical variations and scales. Not surprisingly, the framework was categorized as an "issues-based" framework, as opposed to "geographically-based", in the International Institute for Sustainable Development's global directory of sustainability indicator initiatives (IISD, 2012b).

One of the main drawbacks of an issues-based framework within organizations that possess geographically dispersed operations is that it hinders contextual disclosures. Most, perhaps all, large companies reporting sustainability today have facilities in several or many countries with different ecosystems and political, social, and economic contexts. With the possible exception of GHG emissions and other global quantifiable emissions, the overall contributions to sustainability of a mining company cannot be calculated by a simple aggregation of performance across geographical sites. GRI's protocol on Organizational Boundaries (GRI, 2005) and a paragraph of the guidelines briefly highlight the dangers of aggregating some types of data from different sites: "Reporting organizations should disaggregate information to an appropriate level using the principles and the guidance in the reporting Indicators. Disaggregation may vary by Indicator, but will generally provide more insight than a single, aggregated figure" (GRI, 2006b, p. 37). Nonetheless, these documents do not elaborate on the technical complexities involved in the aggregation or disaggregation processes. Interviewed mining representatives revealed considerable concern about this issue. As one of them said, "I think it [aggregation of data] is a big challenge for all reporters that I know. It is one of the big challenges that we face" (Key informant MP-3). Mining companies have been guided by the GRI to aggregate or disaggregate some indicators, but in trying to do so, they are hampered by the lack of compatible data and unit of analysis across sites. A mining executive exemplified this challenge:

(...) when we talk about GRI, there is a requirement to report on a country by country basis your economic contribution. Well, that type of reporting is complicated, because, at the same time, you've got legally mandated financial reporting in a different way. So we get caught in a situation where we inadvertently have reported information in two different ways and there's not adequate quality control or whatever to ensure that we are in compliance with all the requirements. (Key informant MP-1) 
In reaction to this aggregation problem, mining companies are starting to publish appendixes or webpages with additional data, tables, and statements presented on a facility by facility basis:

(...) what we do in our report, we report on a number of aggregated numbers, like $\mathrm{CO}_{2}$, energy use, and that type of things, water use, but then on our website we have tables, EHS [environment, health and safety] tables, and those are split out by sites. We can put those up there so people can look at what is happening on the individual sites. (Key informant MP-5)

This study found that at least half of the world's twenty largest mining companies (based on figures from Financial Times, 2012) are also publishing facility-level, non-GRI-based sustainability reports, carrying site specific information. This situation seems to indicate a trend towards the publication of facility-level reports. This trend is corroborated by the recent Facility-level Sustainability Reporting Guidelines that are being piloted by CERES, the same institution that created GRI (CERES, 2005; Stoughton and Levy, 2004). This new guideline is supposed to complement the GRI $\mathrm{G} 3$, while bringing more geographical context to disclosures and, at the same, generating information that is relevant to local stakeholders.

The third Bellagio Principle emphasizes the need for not only spatial, but also for appropriate temporal scopes. Meeting the "needs of future generations" requires consideration of time horizons broad enough to capture the time scales of humans and ecosystems. However, such an imperative is difficult to operationalize. Insects, animals, reefs, landscapes, cities, each system component has a particular but interrelated temporal behavior. Capturing the rationale under which they evolve requires understanding their histories, which may be a costly and lengthy process. But, without such understanding, it becomes difficult to identify thresholds or limits against which to assess sustainability. Moreover, given the uncertainties and complexities inherent in socioecological systems, planning over long time periods requires more adaptive approaches that take into account alternatives and scenarios. It is not only spatial hierarchies, but also temporal ones that can be helpful when dealing with time in the pursuit of sustainability strategies (Gunderson and Holling, 2002; Walker et al., 2004).

The GRI G3, in effect, is essentially retrospective despite acknowledging the need to respecting future generations' needs. The framework guides organizations to calculate and understand "past-year" emissions, effluents, compliance and improvements in managerial practices. While partly allowing for benchmarking and comparisons over time, this approach is incapable of properly identifying cumulative impacts and adverse trends in the state of the environment and communities (Lenzen et al., 2004). The framework encourages long-term visions, but in a superficial, elusive way. Scenario building, forecasting or backcasting are largely absent from its requirements. As a result, mining companies' GRI reports tend to omit considerations of future mineral, and other types of, scarcity.

\subsection{Principle 4: conceptual framework and indicators}

The GRI G3 can be considered a simplistic framework when compared to other sustainability frameworks, such as the pressurestate-response, panarchy, and ecosystems-based models (e.g. Holling, 2001; Meadows, 1998; OECD, 2004; Waltner-Toews et al., 2008). The GRI structure promotes the identification of indicators within categories of silos of organizational issues (e.g. strategy, governance, commitments, economy, environment, human rights, labor, etc.). Through the MMSS, the framework also includes a few indicators related to mining and metals issues. However, the GRI does not provide a conceptual framework to help identify the domains that core indicators should cover. In overlooking this principle, the framework may be further contributing to the problem of non-geographical, non-scaled, and non-contextual disclosures.

The GRI G3 has been dismissed as a "shopping list of issues" (Baker and Savitz, 2008) as opposed to a structured sustainability indicator system. Not surprisingly, mining company reports often show simple tables or checklists to communicate their GRI compliance (e.g. Barrick, 2010; Rio Tinto, 2010). The conceptual framework implicit in mining companies' current reporting process, shown in Fig. 2, favors a top-down, 'pillar' approach to identifying non-integrated issues across the company.

On the one hand, the conceptual framework illustrated in Fig. 2 promotes simple, reader-friendly reports, but, on the other hand, it "hides" the complex interactions of the many mining operations with the environment. Fig. 2 is, of course, a tentative and simplified conceptual diagram of what lies behind the identification of sustainability indicators in mining companies reporting processes. It highlights the fact that indicators have been drawn from the companies' exploration, mining, smelting, and refining operations with little consideration for scales and geographical context. Perhaps a more accurate conceptual framework of the current situation would show not only three silos of issues, but arguably many silos covering the GRI G3 indicator categories.

For the purpose of conceptualizing the reporting process in accordance with the fourth Bellagio Principle, the framework would need to be based not on "issues", but on hierarchically nested systems. Fig. 3 presents a tentative diagram of what such a nested systems framework would look like in the context of large mining companies.

Fig. 3 shows many facilities $(1,2, \ldots n)$ across nested socioecological systems from the local to the regional/national and global scales. It also attempts to show the need for a focus on the interactions of mining activities with the external environment, rather than on internal organizational issues. The diagram's many arrows are intended to indicate two ideals: 1) mining facility operators should understand the implications of the life cycles of their operations and minerals to the sustainability of socioecological systems; and 2) the evaluation and reporting process should be capable of capturing the interactions among affected systems within and across scales. Such a conceptual framework would foster the selection of indicators that cover the dynamic and contextual interactions of mining corporations with the external environment.

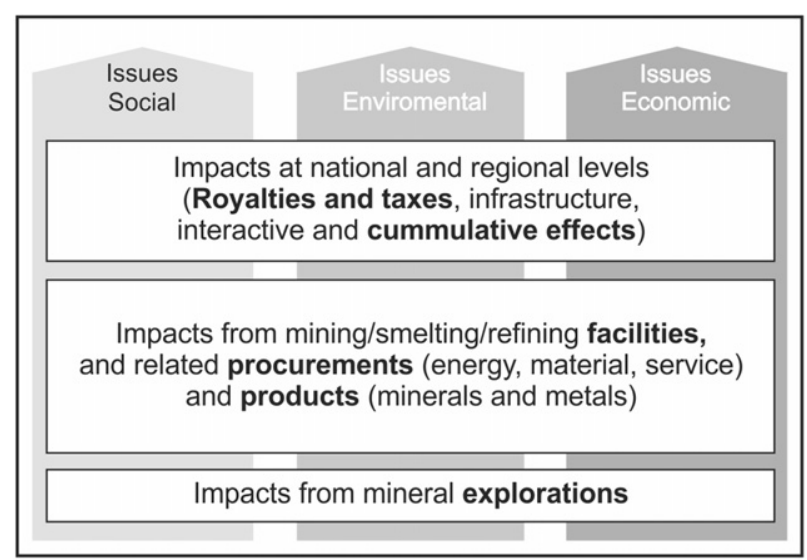

Fig. 2. Tacit conceptual framework of GRI-based sustainability reporting among mining corporations. 


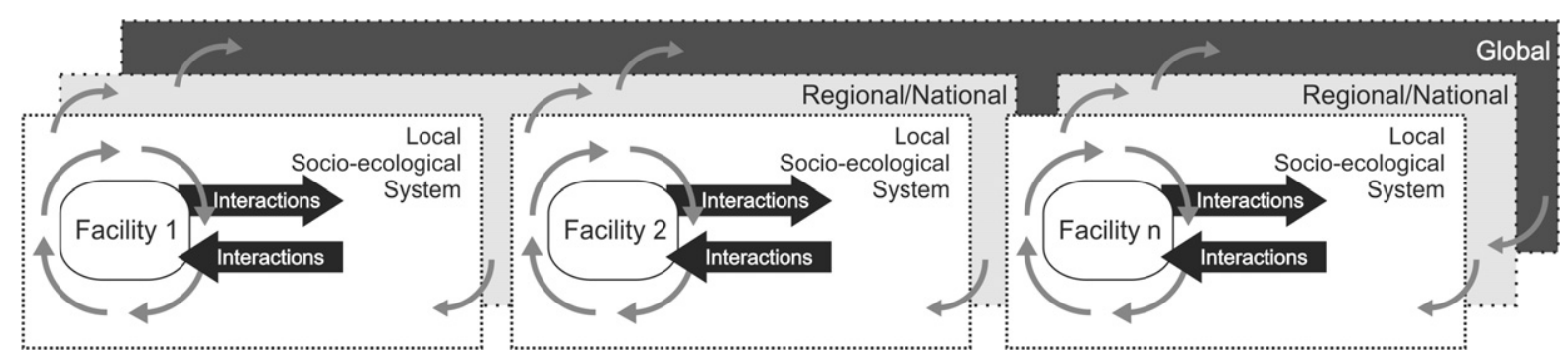

Fig. 3. Desirable conceptual framework of sustainability assessment and reporting among mining corporations.

Currently, the GRI G3 and its MMSS have six indicators on biodiversity (Indicators EN-11-15 and MM-2) that call for an understanding of how the reporting organization is affecting the biodiversity of adjacent areas. But these indicators - in a tacit issues-based conceptual framework - run the risk of translating into generic, non-contextual statements about the company's overall plans and goals related to biodiversity. BHP Billiton's report illustrates this outcome:

We own, manage or lease approximately six million hectares of land (excluding exploration and development projects). As a result of our mining, processing, smelting and petroleum activities, we have disturbed 166,000 hectares of land of which 38,500 hectares have been rehabilitated. We also manage 11,000 hectares of land for biodiversity conservation purposes. (BHP Billiton, 2009, p. 14)

BHP Billiton operates in about 70 locations worldwide. The broad statements and aggregated numbers above have a limited value for biodiversity decision-making at specific sites. After all, has there been progress across all operational sites? For example, a model biodiversity program in a particular site may very well obscure biodiversity losses in different regions. Alternatively, the conceptual framework in Fig. 3, would promote an understanding not only of the "big picture", but also of biodiversity trends within each socio-ecological system, with potential synergies and tradeoffs among them. Of course, the more local the system, the less challenging it should be to understand those trends. The role of particular mining operations in more regional and global systems gets diffused amidst a multiplicity of factors.

Another potential benefit of the framework in Fig. 3 would be the facilitation of evaluations of the controversial issue of mineral scarcity and long-term legacy (Tilton, 1996). Surprisingly, as discussed above, mining corporation's GRI reports tend not to address these relevant sector issues (Mudd, 2007a).

Fig. 3 attempts to present the desirable conceptual framework from the BellagioSTAMP perspective. But such an alternative framework is far more complicated and technically demanding than the tacit GRI one presented in Fig. 2. The framework in Fig. 3 entails numerous barriers, such as the need for additional indicators on the state of the socio-ecological systems impacted by mining activities and related products and procurements. The GRI G3 indicators cover mostly categories of "pressure" and "response" issues, which are insufficient for the purpose of understanding interactions with socio-ecological systems.

The fourth Bellagio Principle also emphasizes the need for reliable data, scenario building, standardized measures, targets and benchmarks. All these elements, with the exception of scenario building, are emphasized by the GRI G3 as well. The purpose of the GRI G3 is precisely to promote reliable, standardized, goal-oriented, and comparable sustainability disclosure. Whether the GRI G3 is effectively promoting these qualities, nonetheless, is a rather contentious issue. For example, many scholars and institutions have been criticizing GRI-based sustainability reports for presenting unreliable information. These critics often argue that corporations are "cherry-picking" issues and manipulating the reporting process to portray an image of a socially and environmentally responsible company (Adams and Evans, 2004; MacLean and Rebernak, 2007). During the research, several interviewees highlighted this problem as well. One of the ways through which GRI tries to promote reliable data is by guiding companies to hire external verification. GRI's Application Level procedure "rewards" externally verified sustainability reports with a "+" symbol. Yet external verification is still a marginal practice (CorporateRegister.com, 2008; Fonseca, 2010). Aware of this problem, ICMM launched an Assurance Procedure that is helping to promote third-party auditing in mining companies' reporting practices. But the role of third-party assurance is not to question the design of the GRI framework; rather it is concerned with the extent to which mining companies are complying with GRI. The auditors do not properly address misinformation, such as optimistic statements and incorrectly aggregated data that may be produced due to the framework's inherent flaws.

\section{Towards the next (effective) generation of sustainability reporting}

Findings from this study indicate that mining corporations' GRI approach to sustainability reporting partly meets Bellagio Principles 1, 2, 3 and 4. Indisputably, the GRI G3 is adding a wide range of sustainability issues, principles, and processes for the consideration of mining corporations that were previously overlooked. In part, this explains why many interviewees believe that the existence of the framework is in itself a reason to celebrate, despite its limitations and problems. As a sustainability assessment researcher said: "I like the fact that it [GRI] exists, that they [mining companies] have a framework in place that reflects a multi-stakeholder process, that organizations can turn to as a starting point to measure their sustainability performance" (Key informant RD-5). As opposed to other mining sustainability frameworks that focus on a few issues, such as Canada's Towards Sustainable Mining Framework (Fitzpatrick et al., 2011), the GRI G3 has more than one hundred indicators covering governance, product responsibility, ecoefficiency, human rights, among many other categories. According to one of the interviewees, this is one of the key strengths of the GRI framework (Key informant MP-4). One sustainability consultant also sees another key strength in the GRI G3: "The fact that there is an international standard is in itself positive, and helps to break through the conservationism [sic] of our leaderships. Because when you approach them [corporate clients] saying 'this is not something I've done', but a global standard, they stop to listen to you" (Key informant CC-2).

The problems of GRI reporting stem first from the misuse of the framework's required principles and indicators. This problem is most often manifested through "cherry-picking". But even if mining corporations were to fully comply with the framework, 
Table 2

Current versus desirable sustainability reporting framework.

\begin{tabular}{|c|c|c|}
\hline $\begin{array}{l}\text { Framework assessment and reporting } \\
\text { aspects }\end{array}$ & Current GRI-based approach & Desirable approach \\
\hline Guiding Vision & $\begin{array}{l}\text { Sustainability, overlooking the need to } \\
\text { operate within the capacity of the biosphere }\end{array}$ & $\begin{array}{l}\text { Sustainability, respecting the need to operate within } \\
\text { the capacity of the biosphere }\end{array}$ \\
\hline Conceptual Framework & Tacit, non-systemic and issues-based & Explicit, geographically-based and scale-based \\
\hline $\begin{array}{l}\text { Evaluation of Trade-offs and Synergies } \\
\text { within and across Systems }\end{array}$ & Overlooked & Assessed, justified, and explained \\
\hline Geographical Scope & Weakly addressed & $\begin{array}{l}\text { Implemented from local to global (facility level, } \\
\text { regional/national-level, and global level reports) }\end{array}$ \\
\hline Temporal Orientation & Predominantly retrospective & $\begin{array}{l}\text { Retrospective and prospective, with scenario building } \\
\text { or forecasting/backcasting techniques, allowing } \\
\text { understanding of legacy effects }\end{array}$ \\
\hline Types of Indicators & Non-integrated, mostly pressure and response & $\begin{array}{l}\text { Non-integrated and integrated, addressing pressure, } \\
\text { state, and response, as well as relationships among them }\end{array}$ \\
\hline $\begin{array}{l}\text { Disclosures of assumptions and } \\
\text { Uncertainties }\end{array}$ & Very Limited & Thorough \\
\hline
\end{tabular}

such an effort would be largely insufficient to structure a sustainability assessment and reporting process that could meet the analyzed Bellagio Principles. The GRI approach to assessing and communicating mining contributions to sustainability has gaps within each analyzed principle. Filling these gaps demands substantial changes in the way mining companies frame their assessments. Table 2 highlights some of the most relevant changes.

The desirable approach to sustainability reporting presented in the third column of Table 2 has been partly emphasized in some of the already cited studies. However, few studies have addressed these issues in the context of mining or have based their analysis on a range of widely endorsed principles. The changes proposed in Table 2 are perhaps the most updated and comprehensive yet proposed for mining corporations. Companies, industry associations, standard-setters, NGOs, investors, communities, and policymakers may find in Table 2 a set of leverage points towards more meaningful sustainability reports in the sector.

The GRI organization might address some of the changes proposed in Table 2 in the (not so near) future. GRI is constantly updating its framework with the participation of a wide range of stakeholders. In 2011, GRI launched an updated version of its framework (the G3.1) which brings some subtle, incremental changes to the previous G3 version (GRI, 2011b). These changes do not address any of the points highlighted in Table 2 (GRI, 2011a). A more robust update, known as GRI G4, is expected to be launched in 2013. The exposure draft of the G4, however, suggests that some of the problems highlighted in this study (e.g. lack of appropriate spatial and temporal scales) are unlikely to be significantly addressed. The draft mentions potential enhancements in the boundary protocol as well as in the guidelines requirements for impacts on the value chains that might translate into a higher, but still largely insufficient, consideration of spatial scales (GRI, 2012a). The above discussed problems of integrated indicators and lack of prospective temporal orientation, which are fundamental for understanding mining's effective legacy effects, is not signaled in the G4 draft. These improvements might come in a fifth or sixth version of the GRI framework, or perhaps in an alternative sustainability reporting system, if standard-setters and mining companies and associations recognize the need for change.

But why would mining companies embrace a "demanding" change of sustainability framework along the lines of the BellagioSTAMP if they are still learning to comply with the simplistic GRI G3? As one of the interviewees puts it:

What we need to do is to take the next step that's gonna make the biggest difference according to what people are doing now. If the mining industry has to put in place an approach to deal a range of issues that generally they are not comfortable with, or have not been comfortable with (because that's new stuff for them,) and if we can do that through introducing a kind of management system that provides this kind of reporting [ideal one], than that is absolutely the ideal thing to do right now. (Key informant MA-1)

Perhaps the mining industry is not yet ready to seriously tackle the challenge of measuring and reporting sustainability. If that is the case, a logical first step, if sustainability was truly the long-term goal, would be to clearly delineate the road ahead and humbly recognize the limitations and side-effects of current reporting practices.

\section{Conclusion}

Depending on one's epistemological perspective, large mining corporations' growing efforts to assess and report contributions to sustainable development are either praiseworthy or worrisome. These practices, arguably, are helping to internalize the vision of sustainability into their corporate ethos, while simultaneously promoting information that can mislead decision-makers and members of the general public. This investigation into the requirements needed to both strengthen the GRI approach among mining corporations and generate meaningful and reliable reports corroborates Nola Buhr's argument that the pathway to an "ideal" reporting system might be much longer than many would like (Buhr, 2007).

Future studies should move beyond the realm of data description, and start grappling with the undeveloped science of measuring and reporting mining sustainability, particularly across geographical sites. The changes proposed in Table 2 would be a good start when developing sounder approaches. Worthwhile and meaningful sustainability reports are likely to depend on a better understanding of context, scales, long-term effects (legacy), interactions, trade-offs, synergies, among others. The technical and motivational barriers to implementing these requirements might appear daunting. One needs to bear in mind, however, that far more daunting are the potential consequences of not effectively progressing towards sustainability.

\section{Acknowledgments}

The authors would like to thank the three reviewers for their valuable comments, as well as the interviewees for sharing their rich insights. Funding for this research was partially granted by the Social Sciences and Humanities Research Council (SSHRC). 


\section{GRI G3.1 MMSS indicators checklist}

\begin{tabular}{|c|c|c|c|}
\hline & \multirow{3}{*}{$\begin{array}{l}\text { GRI CODE } \\
1.1\end{array}$} & \multirow{2}{*}{$\begin{array}{l}\text { Indicators } \\
\text { Statement from the most senior decision-maker of the organization }\end{array}$} \\
\hline \multirow{29}{*}{$\begin{array}{l}\text { Categories } \\
\text { Profile disclosures }\end{array}$} & Strategy and analysis & & \\
\hline & & & Description of key impacts, risks, and opportunities. \\
\hline & Organizational profile & 2.1 & Name of the organization. \\
\hline & & 2.2 & Primary brands, products, and/or services. \\
\hline & & 2.3 & $\begin{array}{l}\text { Operational structure of the organization, including main divisions, } \\
\text { operating companies, subsidiaries, and ioint ventures. }\end{array}$ \\
\hline & & 2.4 & Location of organization's headquarters. \\
\hline & & 2.5 & $\begin{array}{l}\text { Number of countries where the organization operates, and names of } \\
\text { countries with either major operations or that are specifically relevant } \\
\text { to the sustainability issues covered in the report. }\end{array}$ \\
\hline & & 2.6 & Nature of ownership and legal form. \\
\hline & & 2.7 & $\begin{array}{l}\text { Markets served (including geographic breakdown, sectors served, and } \\
\text { types of customers/beneficiaries). }\end{array}$ \\
\hline & & 2.8 & Scale of the reporting organization. \\
\hline & & 2.9 & $\begin{array}{l}\text { Significant changes during the reporting period regarding size, structure, } \\
\text { or ownership. }\end{array}$ \\
\hline & & 2.10 & Awards received in the reporting period. \\
\hline & Report parameters & 3.1 & Reporting period (e.g., fiscal/calendar year) for information provided. \\
\hline & & 3.2 & Date of most recent previous report (if any). \\
\hline & & 3.3 & Reporting cycle (annual, biennial, etc.) \\
\hline & & 3.4 & Contact point for questions. \\
\hline & & 3.5 & Process for defining report content. \\
\hline & & 3.6 & $\begin{array}{l}\text { Boundary of the report (e.g., countries, divisions, subsidiaries, leased } \\
\text { facilities, joint ventures, suppliers). See GRI Boundary Protocol for } \\
\text { further guidance. }\end{array}$ \\
\hline & & 3.7 & $\begin{array}{l}\text { State any specific limitations on the scope or boundary of the report } \\
\text { (see completeness Principle for explanation of scope). }\end{array}$ \\
\hline & & 3.8 & $\begin{array}{l}\text { Basis for reporting on joint ventures, subsidiaries, leased facilities, } \\
\text { outsourced operations, and other entities that can significantly affect } \\
\text { comparability from period to period and/or between organizations. }\end{array}$ \\
\hline & & 3.9 & $\begin{array}{l}\text { Data measurement techniques and the bases of calculations, including } \\
\text { assumptions and techniques underlying estimations applied to the } \\
\text { compilation of the Indicators and other information in the report. }\end{array}$ \\
\hline & & 3.10 & $\begin{array}{l}\text { Explanation of the effect of any re-statements of information provided } \\
\text { in earlier reports, and the reasons for such re-statement (e.g., mergers/ } \\
\text { acquisitions, change of base years/periods, nature of business, } \\
\text { measurement methods). }\end{array}$ \\
\hline & & 3.11 & $\begin{array}{l}\text { Significant changes from previous reporting periods in the scope, } \\
\text { boundary, or measurement methods applied in the report. }\end{array}$ \\
\hline & & 3.12 & Table identifying the location of the Standard Disclosures in the report. \\
\hline & & 3.13 & $\begin{array}{l}\text { Policy and current practice with regard to seeking external assurance } \\
\text { for the report. }\end{array}$ \\
\hline & $\begin{array}{l}\text { Governance, } \\
\text { commitments, } \\
\text { and engagement }\end{array}$ & 4.1 & $\begin{array}{l}\text { Governance structure of the organization, including committees under } \\
\text { the highest governance body responsible for specific tasks, such as } \\
\text { setting strategy or organizational oversight. }\end{array}$ \\
\hline & & 4.2 & $\begin{array}{l}\text { Indicate whether the Chair of the highest governance body is also an } \\
\text { executive officer. }\end{array}$ \\
\hline & & 4.3 & $\begin{array}{l}\text { For organizations that have a unitary board structure, state the number } \\
\text { and gender of members of the highest governance body that are } \\
\text { independent and/or non-executive members. }\end{array}$ \\
\hline & & 4.4 & $\begin{array}{l}\text { Mechanisms for shareholders and employees to provide recommendations } \\
\text { or direction to the highest governance body. }\end{array}$ \\
\hline
\end{tabular}


GRI CODE

\section{5}

Processes in place for the highest governance body to ensure conflicts of interest are avoided.

Process for determining the composition, qualifications and expertise of the members of the highest governance body and its committees,

including any consideration of gender and other indicators of diversity.

Internally developed statements of mission or values, codes of conduct,

and principles relevant to economic, environmental, and social performance and the status of their implementation.

Procedures of the highest governance body for overseeing the organization's identification and management of economic, environmental, and social performance, including relevant risks and opportunities, and adherence or compliance with internationally agreed standards, codes of conduct, and principles.

Processes for evaluating the highest governance body's own performance, particularly with respect to economic, environmental, and social performance. Explanation of whether and how the precautionary approach or principle is addressed by the organization.

Externally developed economic, environmental, and social charters, principles, or other initiatives to which the organization subscribes or endorses.

Memberships in associations (such as industry associations) and/or national/international advocacy organizations. List of stakeholder groups engaged by the organization.

Basis for identification and selection of stakeholders with whom to engage.

Approaches to stakeholder engagement, including frequency of engagement by type and by stakeholder group. Key topics and concerns that have been raised through stakeholder engagement, and how the organization has responded to those key topics and concerns, including through its reporting.

Direct economic value generated and distributed, including revenues, operating costs, employee compensation,

Direct economic value generated and distributed, including revenues, operating costs, employee compensation,
donations and other community investments, retained earnings, and payments to capital providers and governments. Financial implications and other risks and opportunities for the organization's activities due to climate change. Coverage of the organization's defined benefit plan obligations.

Coverage of the organization's defined benefit plan obligations

Significant financial assistance received from government.
Range of ratios of standard entry level wage compared to local minimum wage at significant locations of operation. Range of ratios of standard entry level wage compared to local minimum wage at significant locations of ope
Policy, practices, and proportion of spending on locally-based suppliers at significant locations of operation. Procedures for local hiring and proportion of senior management and workforce hired from the local community at significant locations of operation.

Development and impact of infrastructure investments and services provided primarily for public benefit through commercial, in-kind, or pro bono engagement.

Understanding and describing significant indirect economic impacts, including the extent of impacts. Materials used by weight or volume.

Percentage of materials used that are recycled input materials.

Direct energy consumption by primary energy source.

Indirect energy consumption by primary source.

Energy saved due to conservation and efficiency improvements.

Initiatives to provide energy-efficient or renewable energy based products and services, and reductions in energy requirements as a result of these initiatives.

Initiatives to reduce indirect energy consumption and reductions achieved. Total water withdrawal by source.

Water sources significantly affected by withdrawal of water.

Percentage and total volume of water recycled and reused.

Location and size of land owned, leased, managed in, or adjacent to, protected areas and areas of high biodiversity value outside protected areas.

Description of significant impacts of activities, products, and services on biodiversity in protected areas and areas of high biodiversity value outside protected areas.

Amount of land (owned or leased, and managed for production activities or extractive use) disturbed or rehabilitated. Habitats protected or restored. 
Emissions, effluents and waste

EN16

EN17

EN18

EN19

EN19

EN21

EN21

EN22

EN23

EN24

EN25

Products and services

EN26

EN27

Compliance

Transport

Overall

Social: Labor practices

and decent work

performance

Employment

Labor/management

relations

Occupational healt

and safety

EN29

EN30

LA2

LA15

LA5

MM4

LA6

LA7

LA8

Training and education

A10

LA11

LA12

Social: Human

rights performance

women and men
Diversity and equal

opportunity

Equal remuneration for

Investment and

practices

LA13

LA14

HR1

HR2

HR3

Non-discrimination

Freedom of associatio

and

HR4
HR5
Strategies, current actions, and future plans for managing impacts on biodiversity.

The number and percentage of total sites identified as requiring biodiversity management plans according to stated criteria, and the number (percentage) of those sites with plans in place.

Number of IUCN Red List species and national conservation list species with habitats in areas affected by operations, by level of extinction risk.

Total direct and indirect greenhouse gas emissions by weight.

Other relevant indirect greenhouse gas emissions by weight.

Initiatives to reduce greenhouse gas emissions and reductions achieved.

Emissions of ozone-depleting substances by weight.

$\mathrm{NO}_{x}, \mathrm{SO}_{x}$, and other significant air emissions by type and weight

Total water discharge by quality and destination.

Total weight of waste by type and disposal method.

Total weight of waste by type and disposal method.

Total number and volume of significant spills.

Weight of transported, imported, exported, or treated waste deemed hazardous under the terms of the Basel Convention Annex I, II, III, and VIII, and percentage of transported waste shipped internationally.

Identity, size, protected status, and biodiversity value of water bodies and related habitats significantly affected by the reporting organization's discharges of water and runoff.

Initiatives to mitigate environmental impacts of products and services, and extent of impact mitigation.

Percentage of products sold and their packaging materials that are reclaimed by category.

Monetary value of significant fines and total number of non-monetary sanctions for non-compliance with

environmental laws and regulations.

Significant environmental impacts of transporting products and other goods and materials used for the organization's operations, and transporting members of the workforce.

Total environmental protection expenditures and investments by type.

Total workforce by employment type, employment contract, and region, broken down by gender

Total number and rate of new employee hires and employee turnover by age group, gender, and region.

Benefits provided to full-time employees that are not provided to temporary or part-time employees, by major operations.

Return to work and retention rates after parental leave, by gender.

Percentage of employees covered by collective bargaining agreements.

Minimum notice period(s) regarding significant operational changes, including whether it is specified in collective agreements.

Number of strikes and lock-outs exceeding one week's duration, by country.

Percentage of total workforce represented in formal joint management-worker health and safety committees that help monitor and advise on occupational health and safety programs.

Rates of injury, occupational diseases, lost days, and absenteeism, and number of work-related fatalities by region and by gender.

Education, training, counseling, prevention, and risk-control programs in place to assist workforce members, their families, or community members regarding serious diseases.

Health and safety topics covered in formal agreements with trade unions.

Average hours of training per year per employee by gender and by employee category.

Programs for skills management and lifelong learning that support the continued employability of employees and assist them in managing career endings.

Percentage of employees receiving regular performance and career development reviews.

Composition of governance bodies and breakdown of employees per employee category according to gender, age group minority group membership, and other indicators of diversity.

minority group membership, and other indicators of diversity.
Ratio of basic salary of men to women by employee category.

Percentage and total number of significant investment agreements and contracts that include human rights clauses or that have undergone human rights screening.

Percentage of significant suppliers, contractors, and other business partners that have undergone human rights screening and actions taken.

Total hours of employee training on policies and procedures concerning aspects of human rights that are relevant to operations, including the percentage of employees trained.

Total number of incidents of discrimination and corrective actions taken.

Operations and significant suppliers identified in which the right to exercise freedom of association and collective bargaining may be at significant risk, and actions taken to support these rights. 


\section{GRI G3.1 MMSS indicators checklist}

\section{Categories}

Prevention of forced

and

HR6

compulsory labor

Security practices

Indigenous rights

Assessment

Social: Society

performance

\section{Remediation}

Local communities

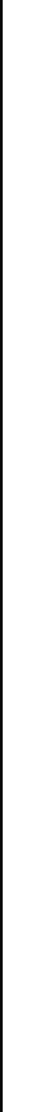

HR8

\begin{tabular}{|l} 
MM5 \\
\hline HR9 \\
HR10 \\
HR11 \\
SO1 (MMSS) \\
SO1 (G3.1) \\
MM6 \\
MM7 \\
\hline
\end{tabular}

SO9
S010

MM8
MM9
MM10

$\mathrm{SO2}$

$\mathrm{SO} 2$

$\mathrm{SO} 3$

SO4

SO6

SO7

SO8

behavior
Compliance

Social: Product

responsibility

Performance

Customer health

PR1

PR2

PR3

Product and service

labeling

Marketing

communications

Customer privacy

Compliance

PR4

PR5
Indicators

Operations identified as having significant risk for incidents of child labor, and measures taken to contribute to the elimination of child labor.

Operations and significant suppliers identified as having significant risk for incidents of forced or compulsory labor, and measures to contribute to the elimination of all forms of forced or compulsory labor.

Percentage of security personnel trained in the organization's policies or procedures concerning aspects of human rights that are relevant to operations.

Total number of operations taking place in or adjacent to Indigenous Peoples' territories, and number and percentage of operations or sites where there are formal agreements with Indigenous Peoples' communities.

operations or sics wes.

Total number of incidents of violations involving rights of indigenous people and actions taken. Percentage and total number of operations that have been subject to human rights reviews and/or impact assessments. Number of grivant Nature, scope, and effectiveness of any programs and practices that assess and manage the impacts of operations on communities, including entering, operating, and exiting.

Percentage of operations with implemented local community engagement, impact assessments, and development programs.

Number and description of significant disputes relating to land use, customary rights of local communities and Indigenous Peoples.

The extent to which grievance mechanisms were used to resolve disputes relating to land use, customary rights of local communities and Indigenous Peoples, and the outcomes.

Operations with significant potential or actual negative impacts on local communities.

Prevention and mitigation measures implemented in operations with significant potential or actual negative impacts on local communities.

Number (and percentage) of company operating sites where artisanal and small-scale mining (ASM) takes place on, or adjacent to, the site; the associated risks and the actions taken to manage and mitigate these risks.

Sites where resettlements took place, the number of households resettled in each, and how their livelihoods were affected in the process.

Number and percentage of operations with closure plans.

Percentage and total number of business units analyzed for risks related to corruption.

Percentage and total number of business units analyzed for risks related to corruption.
Percentage of employees trained in organization's anti-corruption policies and procedures.

Percentage of employees trained in organization's an

Actions taken in response to incidents of corruption.
Public policy positions and participation in public policy development and lobbying

Total value of financial and in-kind contributions to political parties, politicians, and related institutions by country. Total number of legal actions for anti-competitive behavior, anti-trust, and monopoly practices and their outcomes.

Monetary value of significant fines and total number of non-monetary sanctions for non-compliance with laws and regulations.

Programs and progress relating to materials stewardship.

Life cycle stages in which health and safety impacts of products and services are assessed for improvement, and percentage of significant products and services categories subject to such procedures.

Total number of incidents of non-compliance with regulations and voluntary codes concerning health and safety impacts of products and services during their life cycle, by type of outcomes.

Type of product and service information required by procedures, and percentage of significant products and services Type of product and service information requirect to such information requirements.
subject

subject to such information Total num of

information and labeling, by type of outcomes.

Practices related to customer satisfaction, including results of surveys measuring customer satisfaction.

Programs for adherence to laws, standards, and voluntary codes related to marketing communications, including advertising, promotion, and sponsorship.

Total number of incidents of non-compliance with regulations and voluntary codes concerning marketing

communications, including advertising, promotion, and sponsorship by type of outcomes.

Total number of substantiated complaints regarding breaches of customer privacy and losses of customer data.

Monetary value of significant fines for non-compliance with laws and regulations concerning the provision and use of products and services. 


\section{References}

Adams, C.A., Evans, R., 2004. Accountability, completeness, credibility and the audit expectation gap. Journal of Corporate Citizenship 14, 97-115.

Ali, S.H., 2003. Mining, the Environment, and Indigenous Development Conflicts. University Arizona Press, Tucson.

Aras, G., Crowther, D., 2008. Corporate sustainability reporting: a study in disingenuity? Journal of Business Ethics 87, 279-288.

Azapagic, A., 2004. Developing a framework for sustainable development indicators for the mining and minerals industry. Journal of Cleaner Production 12 (6), 639-662.

Baker, M., Savitz, A., 2008. GRI: Sinking or Swimming? GRI Isn't Working for Mallen Baker. Andy Savitz says it's still on track [Online]. Ethical Corporation. Available: http://www.ethicalcorp.com/communications-reporting/debate-\%E2\%80\%93reporting-\%E2\%80\%93-gri-sinking-or-swimming (accessed 29.10.12.)

Barrick, 2010. GRI Indicator List [Online]. Available: http://barrickresponsibility com/2011/gindexes (accessed 29.10.12.)

Bebbington, J., 2001. Sustainable development: a review of the international development, business and accounting literature. Accounting Fortum 25 $128-157$.

Becker, J., 2004. Making sustainable development evaluations work. Sustainable Development 12, 200-211.

Bell, S., Morse, S., 2008. Sustainability Indicators: Measuring the Immeasurable? second ed. Earthscan, London.

BHP Billiton, 2009. Resourcing the Future: Sustainability Summary Report 2009. BHP Billiton Centre, Melbourne.

Bossel, H., 2001. Assessing viability and sustainability: a systems-based approach for deriving comprehensive indicator sets. Ecology and Society. 5. Art. 12

Buhr, N., 2007. Histories of and rationales for sustainability reporting. In: Unerman, J., Bebbington, J., O’Dwyer, B. (Eds.), Sustainability Accounting and Accountability. Routledge, London and New York

Byrch, C., Kearins, K., Milne, M.J., Morgan, R., 2007. Sustainable "what"? A cognitive approach to understanding sustainable development. Qualitative Research in Accounting \& Management 4, 26-52.

Cameron, J., 2009. Avatar, USA/UK, p. 162 min.

CERES, 2005. Facility Reporting Project: Sustainability Reporting Guidance - Pilot Draft. Ceres, Boston, MA

CorporateRegister.com, 2008. Assurance View: the CSR Assurance Statement Report. CorporateRegister.com, London.

Crowther, D., Carter, C., Cooper, S., 2006. The poetics of corporate reporting: evidence from the UK water industry. Critical Perspectives on Accounting 17, 175-201.

Danielson, L., 2006. Architecture for Change: an Account of the Mining, Minerals and Sustainable Development Project History. Global Public Policy Institute, Berlin.

Deloitte, 2007. A Mine of Information. An Analysis of Sustainable Development Reporting in the Mining Industry. Deloitte \& Touche LLP, London.

Devuyst, D., 2000. Linking impact assessment and sustainable development at the local level: the introduction of sustainability assessment systems. Sustainable Development 8, 67-78.

Diesendorf, M., 2001. Models of sustainability and sustainable development International Journal of Agricultural Resources, Governance and Ecology 1, 109-123.

Dunphy, D., Benveniste, J., Griffiths, A., Sutton, P., 2000. Sustainability: The Corporate Challenge of the 21st Century. Allen \& Unwin, Crows Nest, NSW.

Earthworks, 2012. Dirty Gold Campaign [Online]. Available: http://www. nodirtygold.org/home.cfm (accessed 29.10.12.).

Ericsson, M., 2008. Global Mining: New Actors! Raw Materials Group, Solna.

Financial Times, 2012. Financial Times Global 500 2011-Market Values and Prices at 31 March 2011 [Online]. Available: http://media.ft.com/cms/33558890-98d4 11e0-bd66-00144feab49a.pdf (accessed 2.04.12.).

Fitzpatrick, P., Fonseca, A., McAllister, M.L., 2011. From the Whitehorse mining initiative towards sustainable mining. Journal of Cleaner Production 19, 376-384.

FOE, 2002. Phasing Out International Financial Institutions Financing for Fossil Fuel and Mining Projects: Demanding Local Community Self-determination. Friends of the Earth International, Amsterdam.

Fonseca, A., 2010. How credible are mining corporations' sustainability reports? A critical analysis of external assurance under the requirements of the International Council on Mining and Metals. Corporate Social Responsibility and Environmental Management 17, 355-370.

Freeport-McMoRan, 2008. A World of Commitments: Working Toward Sustainable Development: Freeport-McMoRan Copper \& Gold Inc. 2007 Working Toward Sustainable Development Report. Freeport-McMoRan Copper \& Gold Inc, Phoenix.

Geßner, C., Schulz, W.F., Kreeb, M., 2001. What is a good strategy for sustainable development? A draft set of evaluation criteria. Greener Management International, 67-90.

Gifford, B., Kestler, A., 2008. Toward a theory of local legitimacy by MNEs in developing nations: Newmont mining and health sustainable development in Peru. Journal of International Management 14 (4), 340-352.

Gray, R., 2010. Is accounting for sustainability actually accounting for sustainabiltiy. and how would we know? an exploration of narratives of organisations and the planet. Accounting, Organizations and Society 35, 47-62.
Gray, R., Milne, M.J., 2002. Sustainability reporting: who's kidding whom? Chartered Accountants Journal of New Zealand 81, 66-70.

Gray, R., Milne, M.J., 2005. Towards reporting on the triple bottom line: mirages, methods and myths. In: Henriques, A., Richardson, J. (Eds.), The Triple Bottom Line: Does It All Add Up? Earthscan, London, pp. 70-80.

Greenpeace, 2010. Tar Sands in Your Tank [Online]. Available: http://www. greenpeace.org/canada/en/recent/Tar-Sands-in-Your-Tank/ (accessed 20.01.10.). GRI, 2002. Sustainability Reporting Guidelines. Global Reporting Initiative, Boston. GRI, 2005. GRI Boundary Protocol. Global Reporting Initiative, Amsterdam.

GRI, 2006a. GRI Application Levels. Global Reporting Initiative, Amsterdam.

GRI, 2006b. Sustainability Reporting Guidelines. Global Reporting Initiative, Amsterdam.

GRI, 2010. Sustainability Reporting Guidelines \& Mining and Metals Sector Supplement. Global Reporting Initiative, Amsterdam.

GRI, 2011a. GRI G3 and G3.1 Update - Comparison Sheet. Global Reporting Initiative (GRI), Amsterdam.

GRI, 2011b. Sustainability Reporting Guidelines - Version 3.1. Global Reporting Initiative (GRI), Amsterdam.

GRI, 2012a. G4 Development - Second G4 Public Comment Period: G4 Exposure Draft. Global Reporting Initiatives (GRI), Amsterdam.

GRI, 2012b. GRI Sustainability Disclosure Database [Online]. Available: http:// database.globalreporting.org/search (accessed 28.05.12.).

Guenther, E., Hoppe, H., Poser, C., 2006. Environmental corporate social responsibility of firms in the mining and oil and gas industries: current Status Quo of reporting following GRI guidelines. Greener Management International 53, 7-25.

Gunderson, L.H., Holling, C.S., 2002. Panarchy: Understanding Transformations in Human and Natural Systems. Island Press, Washington.

Hardi, P., Zdan, T., 1997. Assessing Sustainable Development: Principles in Practice. International Institute for Sustainable Development, Winnipeg.

Hart, C., 1998. Doing a Literature Review: Releasing the Social Science Imagination. SAGE Publications, London.

Henriques, A., Richardson, J., 2004. The Triple Bottom Line: Does It All Add Up? Earthscan, London.

Hilson, G., Murck, B., 2000. Sustainable development in the mining industry: clarifying the corporate perspective. Resources Policy 26 (4), 227-238.

Hodge, R.A., 1997. Toward a conceptual framework for assessing progress toward sustainability. Social Indicators Research 40, 5-98.

Hodge, A., Hardi, P., Bell, D.V.J., 1999. Seeing Change through the Lens of Sustainability, Beyond Delusion: Science and Policy Dialogue on Designing Effective Indicators of Sustainable Development. Costa Rica, 6-9 May 1999.

Holling, C.S., 2001. Understanding the complexity of economic, ecological, and social systems. Ecosystems 4, 390-405.

ICMM, 2012. ICMM Members [Online]. Available: http://www.icmm.com/members (accessed 28.05.12.)

IISD, 2012a. Compendium: a Global Directory to Indicator Initiatives [Online]. International Institute for Sustainable Development. Available: http://www.iisd. org/measure/compendium/ (accessed 30.07.12.).

IISD, 2012b. Compendium: a Global Directory to Indicator Initiatives - Global Reporting Initiative Details [Online]. International Institute for Sustainable Development (IISD), Winnipeg. Available: http://www.iisd.org/measure/ compendium/DisplayInitiative.aspx?id=1608 (accessed 10.07.12.)

IISD and OECD, 2010. BellagioSTAMP: SusTainability Assessment and Measurement Principles. International Institute for Sustainable Development and Organisation for Economic Co-operation and Development, Winnipeg.

Jenkins, H., 2004. Corporate social responsibility and the mining industry: conflicts and constructs. Corporate Social Responsibility and Environmental Management 11, 23-34

Jenkins, H., Yakovleva, N., 2006. Corporate social responsibility in the mining industry: exploring trends in social and environmental disclosure. Journal of Cleaner Production 14, 271-284.

Kay, P.A., 2000. Measuring sustainability in Israel's water system. Water International 25, 617-623.

Kocsis, T., 2004. New Eldorado, Hungary, p. $76 \mathrm{~min}$.

KPMG, 2006. Global Mining Reporting Survey 2006. KPMG.

KPMG, 2011. KPMG International Survey of Corporate Responsibility Reporting 2011. KPMG, London.

Laine, M., 2005. Meanings of the term "sustainable development" in Finnish corporate disclosures. Accounting Forum 29, 395-413.

Lenzen, M., Dey, C.J., Murray, S.A., 2004. Historical accountability and cumulative impacts: the treatment of time in corporate sustainability reporting. Ecological Economics 51, 237-250.

MacLean, R., Rebernak, K., 2007. Closing the credibility gap: the challenges of corporate responsibility reporting. Environmental Quality Management 16, $1-6$.

Matthews, M., Pearce, R., Chapman, J., 2004. Sustainability Reporting by the Mining Industry: compared with the Requirements of the GRI, Minerals Council of Australia 2004 Inaugural Sustainable Development Conference, Melbourne.

McAller, P., McElhinney, A., 2006. Mine Your Own Business: The Dark Side of Environmentalism, UK, p. $66 \mathrm{~min}$.

McCool, S.F., Stankey, G.H., 2004. Indicators of sustainability: challenges and opportunities at the interface of science and policy. Environmental Management 33, 294-305. 
McElroy, M.W., Jorna, R.J., Engelen, J.v, 2008. Sustainability quotients and the social footprint. Corporate Social Responsibility and Environmental Management 15, 223-234.

Meadows, D.H., 1998. Indicators and Information Systems for Sustainable Development: a Report to the Balaton Group. The Sustainability Institute, Hartland Four Corners.

Milne, M.J., Gray, R., 2007. Future prospects for corporate sustainability reporting. In: Unerman, J., Bebbington, J., O'Dwyer, B. (Eds.), Sustainability Accounting and Accountability. Routledge, London and New York.

MiningWatch, 2004. When Mining Doesn't Work: Towards Sustainable Mining Communities. MiningWatch Canada, Ottawa.

Moneva, J.M., Archel, P., Correa, C., 2006. GRI and the camouflaging of corporate unsustainability. Accounting Forum 30, 121-137.

Morhardt, J.E., 2009. General disregard for details of GRI human rights reporting by large corporations. Global Business Review 10, 141-158.

Mudd, G.M., 2007a. Global trends in gold mining: towards quantifying environmental and resource sustainability? Resources Policy 32, 42-56.

Mudd, G.M., 2007b. The Sustainability of Mining in Australia: Key Production Trends and Their Environmental Implications for the Future. Department of Civil Engineering, Monash University and Mineral Policy Institute, Melbourne.

Mudd, G.M., 2009. Sustainability reporting and mining - an assessment of the state of Play for environmental indicators. In: Proceedings SDIMI 2009 - Sustainable Development Indicators in the Minerals Industry, Gold Coast, Queensland, 6-8 July 2009, Melbourne, pp. 377-391.

Muula, A.S., 2007. How relevant is Bellagio statement of principles on social justice and influenza to Africa? Croatian Medical Journal 48, 752-754.

Nippon, 2007. Sustainabiltiy Report 2007. Nippon Mining Holdings, Inc, Tokyo.

OECD, 2004. Using the Pressure-state-response Model to Develop Indicators of Sustainability. OECD, Paris

Peck, P., Sinding, K., 2003. Environmental and social disclosure and data richness in the mining industry. Business Strategy and the Environment 12,131-146.

Perez, F., Sanchez, L.E., 2009. Assessing the evolution of sustainability reporting in the mining sector. Environmental Management 43, 949-961.

Piper, J.M., 2002. CEA and sustainable development: evidence from UK case studies. Environmental Impact Assessment Review 22, 17-36.

PRI, 2010. "Avatar" in the Amazon [Online]. Public Radio International. Available: http://www.pri.org/arts-entertainment/movies/avatar-in-the-amazon1863. html (accessed 10.07.12.).

Richardson, J., 2004. Accounting for sustainability: measuring quantities or enhancing qualities? In: Henriques, A., Richardson, J. (Eds.), The Triple Bottom Line: Does It All Add Up? Earthscan, London.

Rio Tinto, 2007. Access to Resources, People, Land, Capital: Rio Tinto 2006 Sustainable Development Review. Rio Tinto, London.
Rio Tinto, 2010. GRI checklist [Online]. Available: http://www.riotinto.com/ ourapproach/17212_gri_checklist.asp (accessed 20.01.10.).

Robertson, A.M., Jack, C., 2006. From HSEC Data Verification to Sustainability Assurance - an Evolutionary Process? SD06: Operating for enduring value. Edirol PCR-30 MIDI.

Rotheroe, D., 2000. The Coconut Revolution, UK, p. 50 min.

Schertenleib, R., 2000. The Bellagio Principles and a household centered approach in environmental sanitation, Ecological Sanitation Symposium. gtz, pp. 52-58.

Skouloudis, A., Evangelinos, K., Kourmousis, F., 2009. Development of an evaluation methodology for triple bottom line reports using international standards on reporting. Environmental Management 44, 298-311.

Steurer, R., Langer, M.E., Konrad, A., Martinuzzi, A., 2005. Corporations, stakeholders and sustainable development I: a theoretical exploration of business-society relations. Journal of Business Ethics 61 (3), 263-281.

Stoughton, M., Levy, E., 2004. Voluntary facility-level sustainability performance reporting: current status, relationship to organization-level reporting, and principles for progress. Pace Environmental Law Review 21, 265-287.

Teck, 2007. This Is Our Future: Teckcominco Sustainability Report 2006 [Online] Teck. Available: http://www.teck.com/DocumentViewer.aspx?elementld= 120180\&portalName $=$ tc (accessed 15.07.09.).

Tilton, J.E., 1996. Exhaustible resources and sustainable development. Resources Policy 22, 91-97.

UNEP and KPMG, 2006. Carrots and Sticks for Starters: Current Trends and Approaches in Voluntary and Mandatory Standards for Sustainability Reporting. UNEP and KMPG, Paris.

UNEP, KPMG, GRI, Stellenosch Business School, 2010. Carrots and Sticks: Promoting Transparency and Sustainability - an update on trends in Voluntary and Mandatory Approaches to Sustainability Reporting. New York, Amsterdam, and Belville, Nairobi.

Vale, 2010. 2010 Sustainability Report. Vale, Rio de Janeiro.

Veiga, M., Scoble, M., McAllister, M.L., 2001. Mining with communities. Natural Resources Forum 25, 191-202.

Waard, D.d., Kamp-Roelands, N., 2009. Keep the Balance Steady: Survey on the Quality of Sustainability Reports 2007. Ernst \& Young.

Walker, B., Holling, C.S., Carpenter, S.R., Kinzig, A., 2004. Resilience, adaptability and transformability in social-ecological systems. Ecology and Society 9 [online].

Waltner-Toews, D., Kay, J.J., Lister, N.-M.E., 2008. The Ecosystem Approach: Complexity, Uncertainty, and Managing for Sustainability. Columbia University Press, New York.

WCED, 1987. Our Common Future. Oxford University Press, New York and Oxford

WWF, 2007. WWF Protecting U.S. Southeast Rivers and Streams from Coa Mining [Online]. Available: http://worldwildlife.org/stories/wwf-protecting-us-southeast-rivers-and-streams-from-coal-mining (accessed 20.11.12.).

Xstrata, 2009. Xstrata Sustainability Report 2008. Xstrata plc, Switzerland. 